\title{
EFEK IMPLEMENTASI QUALITY OF WORK LIFE TERHADAP KINERJA SUMBER DAYA MANUSIA TERINTEGRASI (Studi Kasus Usaha Mikro Kecil dan Menengah Di Kota Malang)
}

\author{
Adya Hermawati ${ }^{1)}$, Suhermin ${ }^{2)}$ Rahayu Puji Suci $^{3)}$
}

Email : ${ }^{1}$ ) wati_wati38@yahoo.co.id, ${ }^{2}$ ) hermine_stiesia@yahoo.com, ${ }^{3}$ ) popedot87@gmail.com

1,3) Magister Management Program Pascasarjana Universitas Widyagama Malang

$\left.{ }^{2}\right)$ Sekolah Tinggi Ilmu Ekonomi Indonesia (STIESIA) Surabaya

\begin{abstract}
Abstrak
Tujuan penelitian ini adalah untuk mengetahui pengaruh quality of work life, organizational citizenship behavior, dan keterlibatan kerja terhadap kinerja SDM. Populasi dalam penelitian ini yaitu berjumlah 340 SDM UMKM di Kota Malang. Penentuan jumlah sampel dilakukan dengan menggunakan formula slovin dengan margin error $10 \%$ atau 0,10 diperoleh jumlah sampel sebesar 73. Hasil penelitian menunjukkan bahwa (1) quality of work life berpengaruh tidak signifikan terhadap kinerja SDM; (2) quality of work life berpengaruh signifikan terhadap organizational citizenship behavior, (3) quality of work life berpengaruh signifikan terhadap keterlibatan kerja, 4) organizational citizenship behavior berpengaruh signifikan terhadap kinerja SDM, 5) keterlibatan kerja berpengaruh tidak signifikan terhadap kinerja SDM, 6) quality of work life berpengaruh secara langsung dan tidak langsung terhadap kinerja SDM yang dimediasi oleh organizational citizenship behavior, (7) quality of work life tidak berpengaruh secara langsung dan tidak langsung terhadap kinerja SDM yang dimediasi oleh Keterlibatan kerja, (8) quality of work life (X) tidak berpengaruh secara langsung dan tidak langsung terhadap kinerja SDM yang dimediasi oleh organizational citizenship behavior dan Keterlibatan kerja, dan quality of work life tidak berpengaruh signifikan secara langsung dan tidak langsung terhadap kinerja SDM yang dimediasi oleh organizational citizenship behavior dan keterlibatan kerja.
\end{abstract}

Kata kunci: Quality of work life, organizational citizenship behavior, keterlibatan kerja, kinerja SDM.

\begin{abstract}
The purpose of this study was to determine the effect of quality of work-life, organizational citizenship behavior, and work involvement on HR performance. The population in this study is 340 MSME HR in Malang City. Determination of the number of samples carried out using the Slovin formula with a margin of error of $10 \%$ or 0.10 obtained a sample size of 73 . The results showed that (1) quality of work-life had no significant effect on HR performance; (2) quality of work-life has a substantial impact on organizational citizenship behavior, (3) quality of work-life has a considerable effect on work engagement, 4) corporate citizenship behavior has a significant impact on HR performance, 5) work engagement has no significant effect on HR performance, 6 ) quality of work-life has a direct and indirect impact on HR performance mediated by organizational citizenship behavior, (7) quality of work-life does not directly or indirectly affect HR performance mediated by work involvement, (8) quality of work-life (X) has no direct or indirect effect on HR performance mediated by organizational citizenship behavior and work involvement. Quality of work life does not have a direct and indirect significant impact on HR performance mediated by organizational citizenship behavior and work involvement.
\end{abstract}

Keywords: Quality of work life, organizational citizenship behavior, work involvement, HR performance. 


\section{PENDAHULUAN}

Sumber Daya Manusia (SDM) adalah elemen penting dalam perkembangan Usaha Mikro Kecil dan Menengah (UMKM). Kinerja SDM (employee performance) yang baik tentu saja merupakan harapan bagi semua UMKM yang mempekerjakan pegawainya, sebab kinerja SDM ini pada akhirnya diharapkan dapat meningkatkan kinerja SDM organisasi/UMKM secara keseluruhan. Pada dasarnya kinerja SDM merupakan hasil proses yang kompleks, baik berasal dari diri pribadi pegawai maupun upaya strategis dari dalam UMKM tersebut. Kinerja SDM dapat dipandang sebagai pernyataan positif hasil dari penilaian para pegawai terhadap apa yang telah dilakukan oleh UMKM kepada para pegawainya. Kinerja SDM dipercaya akan dapat menumbuhkan motivasi para pegawai lain untuk tetap tinggal dalam organisasi tersebut.

Sementara quality of work life merupakan suatu konsep atau filsafat manajemen dalam rangka perbaikan kualitas sumber daya manusia yang telah dikenal sejak dekade tujuh puluhan. Pada saat itu quality of work life diartikan secara sempit yaitu sebagai teknik manajemen yang mencakup gugus kendali mutu, perkayaan pekerjaaan, suatu pendekatan untuk bernegosiasi dengan UMKM lain, upaya manajemen untuk memelihara kebugaran mental para pegawai, hubungan industrial yang serasi, manajemen yang partisipatif dan salah satu bentuk intervensi dalam pengembangan UMKM (French, et al., 1990 dalam Noor Arifin, 1999). Dalam perkembangan selanjutnya quality of work life merupakan salah satu bentuk filsafat yang diterapkan oleh manajemen dalam mengelola UMKM pada umumnya dan sumber daya manusia khususnya. Ada empat dimensi di dalam quality of work life yang diharapkan dapat meningkatkan kualitas sumber daya manusia yaitu: 1) partisipasi dalam pemecahan masalah; 2) sistem imbalan yang inovatif; 3) perbaikan lingkungan kerja, dan; 4) restrukturisasi kerja. Quality of work life merupakan masalah utama yang patut mendapat perhatian UMKM (Lewis, et al., 2001). Hal ini merujuk pada pemikiran bahwa quality of work life dipandang mampu untuk meningkatkan peran serta dan sumbangan para anggota atau pegawai terhadap UMKM. Penelitian terdahulu menunjukkan bahwa mutu kehudupan kerja mempunyai dampak positif dan signifikan terhadap kinerja SDM UMKM (May dan Lau, 1999). Quality of work life (MKK) atau Quality of Worklife (QWL) mengacu pada keadaan menyenangkan atau tidak menyenangkannya lingkungan pekerjaan bagi seseorang. Tujuan utamanya adalah pengembangan lingkungan kerja yang sangat baik bagi pegawai dan juga bagi produksi. Fokus utama dari Quality of Worklife sendiri adalah bahwa lingkungan kerja dan semua pekerjaan di dalamnya harus sesuai dengan orang-orang dan teknologi (Davis dan Newstrom, 1994). Sumarsono (2004) mendefinisikan Quality of Worklife sebagai salah satu pendekatan sistem manajemen untuk mengkoordinasikan dan menghubungkan potensi SDM dalam organisasi, sebagai suatu upaya pimpinan untuk memenuhi kebutuhan anggota maupun organisasi secara simultan dan terus menerus. Ada delapan indikator dalam pengukuran quality of work life yang dikembangkan oleh Walton (dalam Zin 2004) tetapi dalam penelitian ini hanya akan digunakan empat indikator saja, yaitu: pertumbuhan dan pengembangan, partisipasi, sistem imbalan yang inovatif, dan lingkungan kerja.

Penelitian Hermawati (2014) membuktkan bahwa quality of work life berpengaruh terhadap OCB. Diketahui bahwa komponen quality of work life, dan variabel-variabel yang berpengaruh secara langsung terhadap OCB adalah pengembangan karir, dan kepuasan kerja. Sedangkan variabel-variabel yang tidak berpengaruh adalah kompensasi, komunikasi, keselamatan lingkungan kerja, penyelesaian masalah, keterlibatan pegawai, ketersediaan fasilitas, rasa aman terhadap pekerjaan dan rasa bangga terhadap UMKM. McCleeland (dalam Shokrkon \& Naami, 2009) juga menyatakan bahwa ada 3 motif yang mendasari timbulnya OCB, yaitu motif berprestasi, motif afiliasi, dan motif kekuasaan. Penelitian yang dilakukan oleh Wyatt dan Wah (2001) terhadap pekerja di Singapura menyebutkan bahwa pekerja ingin diperlakukan sebagai individu yang dihargai di tempat kerja. Kinerja SDM yang bagus akan dihasilkan pekerja jika mereka dihargai dan diperlakukan seperti layaknya manusia dewasa. Hal ini diharapkan dapat menumbuhkan keterlibatan kerja dalam menunjang tujuan organisasi.

Kunci utama dalam keterlibatan kerja adalah bagaimana UMKM fokus terhadap nilai-nilai dasar dalam proses mutu kehudupan kerja. Quality of work life tersebut sangat berpengaruh meskipun belum banyak UMKM yang mengadopsi keterlibatan kerja UMKM sebagai budaya. Penelitian Fields dan Thacker (1992) menunjukkan bahwa suksesnya impelentasi program quality of work life secara keseluruhan berdampak positif terhadap keterlibatan kerja baik terhadap UMKM maupun pada pemerintah. Sementara penelitian Zin (2004) menunjukkan bahwa untuk meningkatkan keterlibatan kerja, UMKM harus mengembangkan quality of work life dengan memberikan kesempatan bagi pegawainya untuk mengembangkan diri melalui program pelatihan dan berpartisipasi dalam setiap pengambilan keputusan yang berhubungan dengan pekerjaan mereka.

Studi empiris menunjukkan bahwa Organizational Citizenship Behavior (OCB) berpengaruh secara langsung terhadap kinerja SDM. Shorkon and Naami (2009) membuktikan bahwa pegawai yang memiliki Organizational Citizenship Behavior (OCB) kuat, akan memiliki kinerja SDM yang lebih baik. Pihak UMKM sebenarnya memerlukan pegawai yang mau mengerjakan melebihi dari tugas mereka seperti biasa dan mengusahakan kinerja SDM melebihi dari seperti yang diharapkan UMKM. Pada kalangan pegawai, pimpinan UMKM perlu membuat perencanaan yang komprehensif terhadap program yang bisa berdampak pada terbentuknya perilaku untuk selalu ingin membantu orang lain dalam tim, melakukan pekerjaan ekstra secara sukarela, menghindari konflik yang tidak perlu, menunjukkan perhatian pada pemimpin UMKM. Contonya adalah memberikan pelatihan kepada pegawainya tanpa memandang suka atau tidak suka tetapi 
harus lebih bersikap profesional untuk memotivasi kinerja SDMnya. Organizational citizenship behavior (OCB) merupakan perilaku individu yang ekstra, yang tidak secara langsung atau eksplisit dapat dikenali dalam suatu sistem kerja yang formal, dan yang secara agregat mampu meningkatkan efektivitas fungsi organisasi (Organ, 1988). Organisasi pada umumnya percaya bahwa untuk mencapai keunggulan harus mengusahakan kinerja SDM yang setinggi-tingginya, karena pada dasarnya kinerja SDM mempengaruhi kinerja SDM tim atau kelompok kerja dan pada akhirnya mempengaruhi kinerja SDM UMKM secara keseluruhan. Menurut Organ (1988), OCB dibangun dari lima dimensi yang masing masingnya bersifat unik, yaitu: Altruism, Civic virtue, Conscientiousness, Courtesy dan Sportsmanship.

Keterlibatan kerja juga dapat dipandang sebagai suatu keadaan yang mana seorang pegawai atau individu memihak pada suatu UMKM tertentu dan tujuantujuannya, serta berniat memelihara keanggotaan dalam UMKM tersebut. Dengan demikian, keterlibatan kerja yang tinggi menunjukkan tingkat keberpihakan seorang pegawai terhadap UMKM yang mempekerjakannya (Eaton, dkk,1992). Hingga saat ini berbagai riset telah membuktikan bahwa keterlibatan kerja terhadap UMKM berpengaruh secara signifikan terhadap work outcomes seperti keinginan untuk pindah kerja, kinerja SDM, tidak ingin menambah pekerjaan, kurangnya inisiatip dan tingkat kemangkiran (Cohen, 1999). Keterlibatan kerja UMKM merupakan pegangan seseorang mengidentifikasi dirinya sebagai bagian dan UMKM dan berkeinginan melanjutkan partisipasi aktif di dalamnya. Keterlibatan kerja yang dimiliki pegawai dalam bekerja tidak lagi dipandang semata-mata mencari nafkah belaka, tetapi lebih mendalam. Dengan adanya konsep quality of work life dimana kebijakan pihak pimpinan memperdayakan UMKM melalui lingkungan kerja yang manusia melalui empat dimensi mutu kehidupan kerja tersebut maka pegawai akan lebih merasa dihargai sehingga keterlibatan kerja juga lebih tinggi. Bila suatu UMKM berupaya mendapatkan keuntungan dari pegawai seperti peningkatan kualitas atau produktivitas, maka UMKM harus menjembatani dan mempunyai keterlibatan kerja UMKM menciptakan suatu lingkungan kerja dimana pegawai didorong untuk memiliki loyalitas yang tinggi dengan kebijakan yang lebih memperhatikan kebutuhan dan kepuasan pegawainya dan memberikan yang terbaik kepada pegawai yang bersangkutan bukan lewat gaji dan fasilitas semata melainkan juga sikap fair dan terbuka dari UMKM terhadap pegawai serta terpeliharanya suasana fun dalam bekerja sehingga tujuan UMKM tercipta.

Kinerja SDM dapat dipandang sebagai pernyataan positif hasil penilaian para pegawai terhadap apa yang telah diberikan UMKM kepada para karyawan. Dari uraian di atas dapat diketahui bahwa quality of work life, OCB, dan keterlibatan kerja terkait dengan kinerja SDM. Kinerja SDM merupakan suatu hasil yang dicapai oleh pekerja dalam pekerjaannya menurut kriteria tertentu yang berlaku untuk suatu pekerjaan tertentu. Kinerja SDM pada umumnya dikatakan sebagai ukuran bagi seseorang dalam pekerjaannya. Kinerja SDM merupakan landasan bagi produktivitas dan mempunyai kontribusi bagi pencapaian tujuan UMKM. Tentu saja kriteria adanya nilai tambah digunakan di banyak perusahaan untuk mengevaluasi manfaat dari suatu pekerjaan dan/atau pemegang jabatan. Kinerja SDM dari setiap pekerja harus mempunyai nilai tambah bagi suatu organisasi atas penggunaan sumber daya yang telah dikeluarkan. Untuk mencapai kinerja SDM yang tinggi, setiap individu dalam UMKM harus mempunyai kemampuan yang tepat (creating capacity to perfor), bekerja keras dalam pekerjaannya (showing the willingness to perform) dan mempunyai kebutuhan pendukung (creating the opportunity to perform). Ketiga faktor tersebut penting, kegagalan dalam salah satu faktor tersebut dapat menyebabkan berkurangnya kinerja SDM, dan pembentukan terbatasnya standard kinerja SDM.

\section{METODE PENELITIAN}

Jenis penelitian yang digunakan yaitu explanatory research yang mencoba untuk menjelaskan hubungan kausal (sebab akibat). Metode pengumpulan data dilakukan dengan survei menggunakan instrumen kuesioner dengan tipe pertanyaan tertutup (closed-ended question). Metode penelitian yang digunakan dalam penelitian ini adalah metode survei. Penelitian ini bersifat korelasional karena penelitian berusaha menyelidiki hubungan antara beberapa variabel penelitian yaitu variabel Quality of work life sebagai variable bebas, OCB dan Keterlibatan kerja sebagai variabel antara terhadap Kinerja SDM sebagai variabel terikat. Menurut Hamid \& Patra (2019) sampel adalah keseluruhan objek atau subyek maupun individu pada suatu wilayah yang akan diteliti. Populasi dalam penelitian ini adalah semua karyawan (340) UMKM Malang Kota. Menurut Hamid \& Patra (2019) sampel adalah kumpulan atau bagian dari populasi yang terpilih dengan prosedur tertentu yang bisa merepresentasikan populasi. Dalam penelitian ini pengambilan sampel dilakukan dengan menggunakan rumus Slovin sejumlah 73 orang. Teknik pengambilan sampel yang digunakan dalam penelitian ini adalah probability sampling dengan teknik proportional random sampling dikarenakan unit instansi terdiri dari beberapa bagian. Pengujian hipotesis dilakukan dengan menggunakan teknik path analysis dengan bantuan software SPSS Versi 22.

\section{HASIL DAN PEMBAHASAN}

\section{Uji Instrumen Validitas dan Reliabilitas Variabel Uji Validitas}

Pengujian validitas dalam penelitian ini mempergunakan analisis korelasi product moment, dengan mengkorelasikan skor setiap item dengan skor total sebagai jumlah skor item. Kriteria pengujian validitas adalah Jika probabilitas $<0,05$ maka butir pertanyaan valid dan sebaliknya jika probabilitas $>0,05$ maka butir pertanyaan tidak valid. Diketahui bahwa nilai Sig. (2-tiled) untuk semua ítem variabel Quality of work life, Organizational Citizenship Behavior, Keterlibatan kerja dan variabel Kinerja Sumber Daya Manusia berada 
di bawah 0.05 . Hal ini dapat dikatakan bahwa semua ítem pada variabel tersebut valid.

\section{Uji Reliabilitas}

Pengujian reliabilitas instrumen dilakukan pada item pertanyaan yang sudah valid. Instrumen dinyatakan reliabel jika nilai reliabilitas yang diperoleh lebih besar dari 0.6. Hasil uji reliabilitas menunjukkan bahwa nilai Cronbach alpha untuk variabel Kinerja Sumber Daya Manusia sebesar 0.969, Quality of work life sebesar 0.956, Organizational Citizenship Behavior sebesar 0.942 dan Keterlibatan kerja sebesar 0.725, dimana seluruh variabel yang digunakan didalm penelitian ini memiliki nilai Cronbach alpha lebih besar dari 0.6 sehingga instrumen yang digunakan dinyatakan reliabel.

\section{Analisis Statistik Deskriptif}

Dalam penelitian ini peneliti menggunakan analisis deskriptif atas variabel independen dan dependennya yang selanjutnya dilakukan pengklasifikasian terhadap jumlah total skor responden. Dari jumlah skor-jawaban responden yang diperoleh kemudian disusun kriteria penilaian untuk setiap item pernyataan. Untuk menjawab deskripsi tentang masing-masing variabel penelitian, maka digunakan rentang kriteria penilaian sebagai berikut: 1) skala 1.00-1.80 dikategorikan sebagai "Sangat Rendah"; 2) skala 1.81-2.60 dikategorikan sebagai "Rendah"; 3) skala 2.61-3.40 dikategorikan sebagai "Sedang"; 4) skala 3.41-4.20 dikategorikan sebagai "Tinggi" dan, 5) skala 4.21-5.00 dikategorikan sebagai "Sangat Tinggi" (Arikunto, 2006).

Untuk variabel Quality of work life, Hasil perhitungan menunjukkan bahwa QWL masuk ke dalam kriteria kuat, hal ini dapat dilihat dari skor rata-rata yang dihasilkan sebesar 3.82 dan berdasarkan rentang skor rata-rata berada pada interval 3.41-4.20 yang berarti masuk dalam klasifikasi penilaian kuat. Selanjutnya untuk variabel Organizational Citizenship Behavior, Hasil perhitungan menunjukkan bahwa Organizational Citizenship Behavior masuk ke dalam kriteria kuat, hal ini dapat dilihat dari skor rata-rata yang dihasilkan sebesar 4.35 dan berdasarkan rentang skor rata-rata berada pada interval 3.41-4.20 yang berarti masuk dalam klasifikasi penilaian sangat kuat. Kemudian untuk variabel Keterlibatan kerja, Hasil perhitungan menunjukkan bahwa Keterlibatan kerja masuk ke dalam kriteria kuat, hal ini dapat dilihat dari skor rata-rata yang dihasilkan sebesar 3.91 dan berdasarkan rentang skor rata-rata berada pada interval 3.41-4.20 yang berarti masuk dalam klasifikasi penilaian kuat. Sementara untuk variabel Kinerja Sumber Daya Manusia, Hasil perhitungan menunjukkan bahwa Kinerja SDM masuk ke dalam kriteria kuat, hal ini dapat dilihat dari skor rata-rata yang dihasilkan sebesar 3.89 dan berdasarkan rentang skor rata-rata berada pada interval 3.41-4.20 yang berarti masuk dalam klasifikasi penilaian kuat.

\section{Pembahasan Hasil Pengujian Hipotesis (Path Analysis)}

Guna menguji pengaruh variabel perantara atau intervening maka digunakan metode analisis jalur (path analysis). Analisis jalur adalah hasil perluasan analisis regresi linear berganda. Analisis jalur digunakan untuk mengetahui apakah data mendukung teori yang mencakup kaitan struktural antara variabel terukur. Analisis jalur atau lebih dikenal sebagai path analysis merupakan suatu metode mengkomposisikan korelasi ke dalam bagian-bagian yang berbeda untuk menginterpretasikan suatu pengaruh.

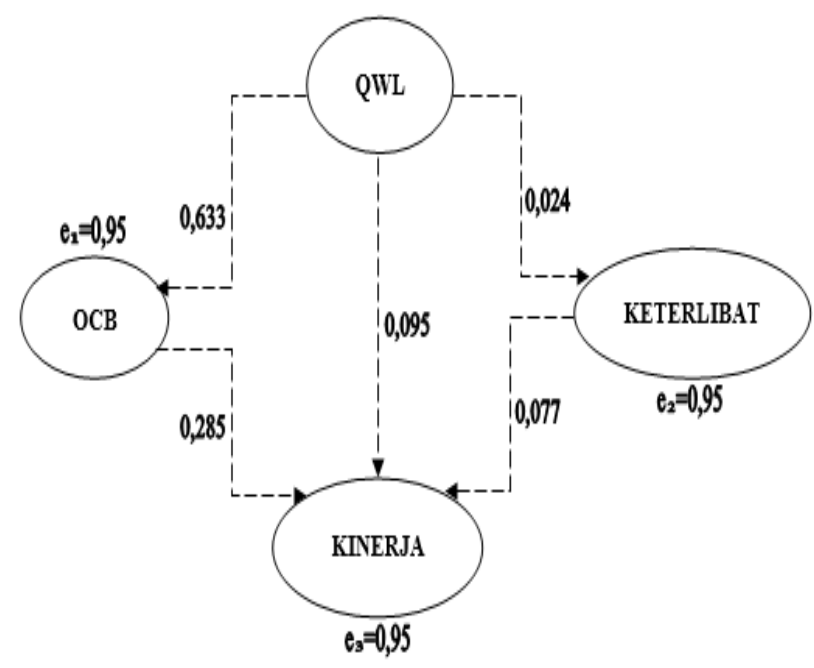

Gambar 1. Diagram Analisis Jalur

Berdasarkan hasil pengujian path analysis pada gambar 1. Selanjutnya akan diuraikan hasil pengujian hipotesis berdasarkan pada jalur (path) masing masing variabel.

Hipotesis 1 menyatakan bahwa Quality of work life tidak berpengaruh signifikan terhadap Kinerja SDM. Hasil penelitian menunjukkan bahwa nilai probabilitas ( $p$-value) hubungan antara variabel Quality of work life $\rightarrow$ kinerja SDM sebesar 0.380 yang lebih besar dari 0.05 $(0.380>0.05)$. Hal tersebut menyatakan bahwa Quality of work life berpengaruh tidak signifikan terhadap Kinerja SDM. Dapat disimpulkan bahwa hipotesis 1 yang menyatakan bahwa Quality of work life berpengaruh tidak signifikan terhadap Kinerja SDM pegawai tidak diterima. Quality of work life belum berkontribusi terhadap kinerja SDM. Hal ini berarti bahwa quality of work life yang dirasakan SDM UMKM Kota Malang masih belum mampu meningkatkan kinerja SDM pada UMKM Kota Malang.

Hipotesis 2 menyatakan bahwa Quality of work life berpengaruh signifikan terhadap organizational citizenship behavior. Hasil penelitian menunjukkan bahwa nilai probabilitas ( $p$-value) hubungan antara variabel Quality of work life $\rightarrow$ organizational citizenship behavior sebesar 0.030 yang lebih kecil dari $0.05(0.030<0.05)$. Hal tersebut menyatakan bahwa Quality of work life berpengaruh signifikan terhadap Organizational Citizenship Behavior. Dapat disimpulkan bahwa hipotesis 2 yang menyatakan bahwa Quality of work life berpengaruh signifikan terhadap organizational citizenship behavior dapat diterima. Quality of work life berkontribusi terhadap organizational citizenship behavior. Hal ini berarti bahwa quality of work life yang baik mampu meningkatkan organizational citizenship behavior. 
Hipotesis 3 menyatakan bahwa Quality of work life tidak berpengaruh signifikan terhadap Keterlibatan kerja. Hasil penelitian menunjukkan bahwa nilai probabilitas ( $p$-value) hubungan antara variabel Quality of work life $\rightarrow$ Keterlibatan kerja sebesar 0.829 yang lebih besar dari $0.05(0.829>0.05)$. Hal tersebut menyatakan bahwa Quality of work life berpengaruh tidak signifikan terhadap Keterlibatan kerja. Dapat disimpulkan bahwa hipotesis 3 yang menyatakan bahwa Quality of work life berpengaruh tidak signifikan terhadap Keterlibatan kerja tidak diterima. Quality of work life masih belum berkontribusi terhadap keterlibatan kerja pada UMKM. Hal ini berarti bahwa quality of work life yang dirasakan SDM UMKM Kota Malang masih belum mampu meningkatkan keterlibatan kerja.

Hipotesis 4 menyatakan organizational citizenship behavior berpengaruh signifikan terhadap kinerja SDM. Hasil penelitian menunjukkan bahwa nilai probabilitas ( $p$-value) hubungan antara variabel organizational citizenship behavior $\rightarrow$ kinerja SDM sebesar 0.020 yang lebih kecil dari $0.05(0.020<0.05)$. Hal tersebut menyatakan bahwa organizational citizenship behavior berpengaruh signifikan terhadap kinerja SDM. Dapat disimpulkan bahwa hipotesis 4 yang menyatakan bahwa organizational citizenship behavior berpengaruh signifikan terhadap kinerja SDM pegawai dapat diterima. OCB ternyata mampu berkontribusi terhadap kinerja SDM UMKM Kota Malang. Hal ini berarti bahwa OCB yang baik mampu meningkatkan kinerja SDM.

Hipotesis 5 menyatakan bahwa Keterlibatan kerja tidak berpengaruh signifikan terhadap Kinerja SDM. Hasil penelitian menunjukkan bahwa nilai probabilitas ( $p$-value) hubungan antara variabel Keterlibatan kerja $\rightarrow$ Kinerja SDM sebesar 0.479 yang lebih besar dari 0.05 $(0.479>0.05)$. Hal tersebut menyatakan bahwa Keterlibatan kerja berpengaruh tidak signifikan terhadap Kinerja SDM. Dapat disimpulkan bahwa hipotesis 5 yang menyatakan bahwa Keterlibatan kerja berpengaruh tidak signifikan terhadap Kinerja SDM tidak diterima. Ternyata keterlibatan kerja masih belum mampu berkontribusi terhadap kinerja SDM UMKM Kota Malang. Hal ini berarti bahwa keterlibatan kerja yang dirasakan masih belum mampu meningkatkan kinerja SDM UMKM Kota Malang.

Hipotesis 6 menyatakan quality of work life berpengaruh signifikan terhadap kinerja SDM melalui organizational citizenship behavior. Berdasarkan hasil analisis menunjukkan bahwa quality of work life berpengaruh langsung terhadap Kinerja SDM, dan dapat juga berpengaruh tidak langsung yaitu melalui Organizational Citizenship Behavior. Dapat disimpulkan bahwa hipotesis 6 yang menyatakan quality of work life berpengaruh signifikan terhadap kinerja SDM melalui organizational citizenship behavior dapat diterima. Quality of work life terhadap kinerja SDM yang dimediasi oleh OCB ternyata mampu meningkatkan kinerja SDM UMKM Kota Malang. Hal ini berarti quality of work life yang dimediasi OCB mampu membuat kinerja SDM maksimal.

Hipotesis 7 menyatakan quality of work life tidak berpengaruh tidak berpengaruh terhadap kinerja SDM pegawai melalui Keterlibatan kerja. Berdasarkan hasil analisis menunjukkan bahwa quality of work life berpengaruh langsung terhadap Kinerja SDM, dan dapat juga berpengaruh tidak langsung yaitu melalui Keterlibatan kerja. Dapat disimpulkan bahwa hipotesis 7 yang menyatakan quality of work life berpengaruh signifikan terhadap kinerja SDM pegawai melalui Keterlibatan kerja dapat diterima. Quality of work life terhadap kinerja SDM yang dimediasi oleh keterlibatan kerja ternyata belum mampu meningkatkan kinerja SDM UMKM Kota Malang. Ini karena quality of work life melalui atau tidak melalui keterlibatan kerja masih belum mampu meningkatkan kinerja SDM.

Hipotesis 8 menyatakan quality of work life tidak berpengaruh terhadap kinerja SDM melalui organizational citizenship behavior Keterlibatan kerja. Berdasarkan hasil analisis menunjukkan bahwa quality of work life berpengaruh langsung terhadap Kinerja SDM, dan dapat juga berpengaruh tidak langsung yaitu melalui organizational citizenship behavior Keterlibatan kerja. Dapat disimpulkan bahwa hipotesis 8 yang menyatakan quality of work life berpengaruh signifikan terhadap kinerja SDM melalui organizational citizenship behavior Keterlibatan kerja dapat diterima. Melihat pengaruh total ternyata masih belum berkontribusi terhadap kinerja SDM. Hal ini berarti perlu adanya belum adanya kemampuan dari semua pengaruh total untuk mendongkrak kinerja SDM.

\section{PENUTUP}

\section{Simpulan}

Berdasarkan pada hasil dan pembahasan yang telah diuraikan sebelumnya, maka dapat disimpulkan bahwa:

1. Quality of work life belum berkontribusi terhadap kinerja SDM. Hal ini berarti bahwa quality of work life yang dirasakan SDM UMKM Malang Kota masih belum mampu meningkatkan kinerja SDM mereka.

2. Selanjutnya quality of work life berkontribusi terhadap organizational citizenship behavior (OCB). Hal ini berarti bahwa quality of work life yang baik mampu meningkatkan OCB.

3. Untuk quality of work life masih belum berkontribusi terhadap keterlibatan kerja pada UMKM. Hal ini berarti bahwa quality of work life yang dirasakan SDM UMKM Malang Kota masih belum mampu meningkatkan keterlibatan kerja.

4. Kemudian untuk OCB ternyata mampu berkontribusi terhadap kinerja SDM. Hal ini berarti bahwa OCB yang baik mampu meningkatkan kinerja SDM.

5. Selanjutnya untuk keterlibatan kerja juga masih belum mampu berkontribusi terhadap kinerja SDM. Hal ini berarti bahwa keterlibatan kerja yang dirasakan pegawai masih belum mampu meningkatkan kinerja SDM.

6. Kemudian untuk quality of work life terhadap kinerja SDM yang dimediasi oleh OCB ternyata mampu meningkatkan kinerja SDM. Hal ini berarti quality of work life yang dimediasi OCB mampu membuat kinerja SDM maksimal. 
7. Untuk Quality of work life terhadap kinerja SDM yang dimediasi oleh keterlibatan kerja ternyata belum mampu meningkatkan kinerja SDM. Ini karena quality of work life melalui atau tidak melalui keterlibatan kerja masih belum mampu meningkatkan kinerja SDM.

8. Selanjutnya untuk Melihat pengaruh total ternyata masih belum berkontribusi terhadap kinerja SDM. Hal ini berarti perlu adanya belum adanya kemampuan dari semua pengaruh total untuk mendongkrak kinerja SDM.

\section{Saran}

Dalam konsep MSDM (Manajemen Sumber Daya Manusia) modern, Sumber Daya Manusia (Man Power) dipandang sebagai salah satu asset perusahaan yang sangat penting dengan terminologi Human Capital sehingga SDM tetap konsistensi penting meningkatkan kontribusi pada UMKM. Man Power merupakan salah satu faktor yang menentukan keberhasilan dan kesuksesan suatu perusahaan, oleh karena itu kunci keberhasilan MSDM adalah bagaimana mengelola SDM (Man Power) yang ada untuk dapat dibina, dipelihara dan dioptimalisasikan secara efisien dan se-efektif mungkin dengan pola-pola pendekatan profesionalisme dalam bekerja. MSDM dituntut menemukan strategi - strategi HR yang dapat menyesuaikan dengan situasi dan kondisi yang semakin berkembang dan berubah-ubah dengan cepatnya, iklim persaingan semakin ketat dan mengglobal, strategi - strategi diterapkan dalam rangka menemukan formulasi yang paling efektif dan efisien dalam penggunaan Man Power. Organisasi perusahaan sudah saatnya semakin dirampingkan, model organisasi piramidal yang mengenal banyaknya jenjang dan birokrasi yang berbelit sudah semakin ditinggalkan, organisasi yang lebih datar mulai diterapkan dengan rantai komando yang lebih efektif namun dengan tetap mengacu pada prosedur - prosedur kerja yang ketat. Hal ini dapat diakomodir dengan pola pendekatan MSDM modern yang menerapkan strategi - strategi HR yang mengarah pada peningkatan profesionalisme SDM dan penyerapan teknologi informasi.

\section{DAFTAR PUSTAKA}

Arikunto, S. 2006. Metode Penelitian Kualitatif. Jakarta: Bumi Aksara.

Arifin, Noor. 1999. Aplikasi Konsep Quality of Work Life dalam Upaya Menumbuhkan Motivasi Karyawan Berkinerja SDM Unggul. Usahawan, No. 10, hal 25-29

Davis, K. \& Newstrom. 1994. Perilaku dalam Organisas, Alih Bahasa: Agus Dharma Jilid Satu. Jakarta: Erlangga.

Eaton, Adrianne E., Michael E. Gordon and Jeffrey H. Keefe. 1992. The Impact of Quality of Work Life Programs and Grievance System Effectiveness on Union Commitment. Industrial and Labour Relations Review. 45(3), 591-604.
Fields and Thacker. 1992. Influence of Quality of Work Life on Company and Union Commitment. Academy of Management Journal, 35(2), 439-450.

Hamid, R. S., \& Patra, I Ketut. 2019. PENGANTAR STATISTIKA UNTUK RISET BISNIS DAN EKONOMI Konsep Dasar dan Aplikasi SPSS versi 25. Banten: CV. AA. RIZKY.

Hermawati, Adya. 2014. QWL and Organizational Trust Related to Job Satisfaction and Organizational Commitment at Privete Higher Education Institution in Malang-Indonesia. Journal of Basic and Applied Scientific Research. 4(2)

HM. Sonny Sumarsono. 2004. Metode Riset Sumber Daya Manusia, Jember: Graha Ilmu.

May, B. E., \& Lau, R. S. 1999. A Longitudinal Study of Quality of Work Life and Business Performance. South Dakota Review. 58(2), 3-7

Organ, D. W. 1988. Organizational citizenship behavior: The good soldier syndrome. Lexington, MA: Lexington Books.

Shokrkon,H and Naami, A. 2009. The Relationship of Job Satisfaction with Organizational Citizenship Behavior and Job performance in Ahvas Factory Workers. Journal of Education and Psychology. 3(2), 39-52.

Zin, Razali Mat. 2004. Perception of Profesional Engineers Toward Quality of Work Life and Organizational Commitment. Gajah Mada Iternational Journal of Business. 6(3), 323-334. 